\title{
Nuclear receptors: a bridge linking the gut microbiome and the host
}

\author{
Zixuan Wang ${ }^{1}$, Wei-Dong Chen ${ }^{2,3^{*}}$ and Yan-Dong Wang ${ }^{1 *}$ (i)
}

\begin{abstract}
Background: The gut microbiome is the totality of microorganisms, bacteria, viruses, protozoa, and fungi within the gastrointestinal tract. The gut microbiome plays key roles in various physiological and pathological processes through regulating varieties of metabolic factors such as short-chain fatty acids, bile acids and amino acids. Nuclear receptors, as metabolic mediators, act as a series of intermediates between the microbiome and the host and help the microbiome regulate diverse processes in the host. Recently, nuclear receptors such as farnesoid X receptor, peroxisome proliferator-activated receptors, aryl hydrocarbon receptor and vitamin $D$ receptor have been identified as key regulators of the microbiome-host crosstalk. These nuclear receptors regulate metabolic processes, immune activity, autophagy, non-alcoholic and alcoholic fatty liver disease, inflammatory bowel disease, cancer, obesity, and type-2 diabetes.
\end{abstract}

Conclusion: In this review, we have summarized the functions of the nuclear receptors in the gut microbiome-host axis in different physiological and pathological conditions, indicating that the nuclear receptors may be the good targets for treatment of different diseases through the crosstalk with the gut microbiome.

Keywords: Gut microbiome, Nuclear receptors, Inflammatory bowel disease, Obesity, Diabetes

\section{Introduction}

The gut microbiome is the totality of microorganisms, bacteria, viruses, protozoa, and fungi within the gastrointestinal tract (Corrigan et al. 2018). And it plays various roles in different physiological and pathological conditions (Backhed et al. 2005). The composition of the microbiome in the intestine is diverse and depends upon the environment, gender, diet, age, immune system, xenobiotic exposure, etc. (Feng et al. 2018). In recent years, an increasing number of reports have shown the interactions between the host and microbiome but the underlying mechanisms remain unclear (Tremaroli and

\footnotetext{
*Correspondence: wdchen666@163.com; ydwangbuct2009@163.com 1 State Key Laboratory of Chemical Resource Engineering, College of Life Science and Technology, Beijing University of Chemical Technology, Beijing, People's Republic of China

${ }^{2}$ Key Laboratory of Molecular Pathology, Key Laboratory of Receptors-Mediated Gene Regulation and Drug Discovery, School of Basic Medical Science, Inner Mongolia Medical University, Hohhot, Inner Mongolia, People's Republic of China

Full list of author information is available at the end of the article
}

Backhed 2012). These interactions are involved in various processes such as metabolism (Federici 2019), immunomodulation (du Teil Espina et al. 2019) and autophagy (Jin et al. 2015). The gut microbiome affects host physiology and host condition alters the gut microbiome composition. For example, the phenotype of high-fatdiet-induced weight gain will be transferred to germ-free mice through fecal microbiota transplant, indicating the gut microbiome affects the host while some gene knockout mice have the altered gut microbiota compared with wild-type mice (Parséus et al. 2017). These reports indicate that the gut microbiome can be regarded as a subsystem in the intestine. The gut microbiome is related to various diseases such as obesity, diabetes, clinic inflammation and cancer. The gut microbiome affects nuclear receptors (NRs) through a variety of factors such as bile acids (BAs), short-fatty acids (SCFAs) and Vitamins. And the roles of NRs in various pathological and physiological processes of the host can be changed by this effect. In original author(s) and the source, provide a link to the Creative Commons licence, and indicate if changes were made. The images or other third party material in this article are included in the article's Creative Commons licence, unless indicated otherwise in a credit line to the material. If material is not included in the article's Creative Commons licence and your intended use is not permitted by statutory regulation or exceeds the permitted use, you will need to obtain permission directly from the copyright holder. To view a copy of this licence, visit http://creativecommons.org/licenses/by/4.0/. 
other words, NRs play different roles as intermediaries or a bridge between the gut microbiome and the host.

NRs are a group of ligand-binding transcription factors and mediators of various metabolic and signaling pathways (Chawla et al. 2001). NR superfamily includes various members such as farnesoid $\mathrm{X}$ receptor (FXR), Liver $X$ receptor ( $L X R$ ), retinoid $X$ receptor ( $R X R$ ), pregnane and xenobiotic receptor (PXR), peroxisome proliferatoractivated receptors (PPARs), constitutive androstane receptor (CAR), Vitamin $D$ receptor (VDR), and aryl hydrocarbon receptor (AHR) (Cave et al. 2016; Zenata and Vrzal 2017; Murray et al. 2014). The abnormal states of NRs may lead to serious consequences (Lazar 2017). For example, knockout or low activation of FXR will cause a significant reduction in the rate of liver regeneration, and FXR knockout mice show higher tumor incidence (Wang et al. 2008a). These characteristic functions of NRs imply that they could be potential therapeutic targets in many diseases.

The correlation between the gene expression of the host and the composition of the microbiota has been reported increasingly often (Kurilshikov et al. 2017), indicating that the gut microbiota may have some relationships with transcription factors such as NRs. For example, SCFAs are the products of the gut microbiota and can activate PPARY in the colon and regulate the process of inflammatory bowel disease (IBD) (Viladomiu et al. 2013). Meanwhile, the microbiota compositions are associated with endogenous factors including host-produced BAs regulated by FXR (Zheng et al. 2017). These reports indicate that NRs-microbiota axis plays key roles in the whole metabolic and signaling system. To date, FXR (Shapiro et al. 2018), AHR (Hubbard et al. 2015), VDR (Wang et al. 2016a), and PPARs (Mishra et al. 2016) have been confirmed to be closely related to the gut microbiota. It suggests that NRs could be identified as bridges between the gut microbiota and the host system.

In this review, we discussed that the physiological and pathological implications of NRs (mainly FXR, AHR, VDR, and PPARs)-gut microbiota axis and these functions are not limited to the intestine but also can be found in other organs.

\section{NRs: the intermediary of the host and gut microbiome}

NRs have been identified as the intermediaries between the gut microbiota and the host system, even making the microbiota as an essential "independent organ" (Wahlstrom et al. 2016). In other words, NRs could be identified as a family of molecular messengers for the gut microbiota to interact with the host system (Arulampalam et al. 2006). For example, numerous genera or species of the gut microbiome can produce indole (e.g.
E.coli) or SCFAs (e.g. Clostridium and Lactobacillus), some stimuli such as diet can change the abundance of these genera or species to affect the levels of indole or SCFAs (Hubbard et al. 2015; Zhao et al. 2018). Indole is the ligand of AHR (Marinelli et al. 2019), and SCFAs are the ligands of AHR and PPARs (Marinelli et al. 2019; Roy et al. 2016). These NRs are associated with various host activities such as diseases including IBD, non-alcoholic fatty liver disease (NAFLD), and alcoholic liver disease (ALD) (Hendrikx et al. 2018; Jiao et al. 2018; Lamas et al. 2016a; Mir et al. 2013). The activation of PPAR $\gamma$ by its ligand decreases cecal lactate levels during Salmonella enterica Typhimurium infection (Gillis et al. 2018). And VDR can maintain the antimicrobial function of Paneth cells in the gut to maintain the gut microbiome homeostasis (Wu et al. 2015). A few of the NRs-gut microbiota crosstalk mechanisms are summarized in Table 1.

\section{Gut microbiota and FXR}

FXR was first identified and named in 1995 (Forman et al. 1995). It belongs to a sub-cluster of receptors (including VDR, CAR, PXR, LXR $\alpha$, etc.) that are metabolic regulators (Wang et al. 2008a). As a transcription factor, FXR can bind to DNA as a monomer or heterodimer with RXR and regulate the target gene expression. It, however, was identified as an orphan nuclear receptor initially (Kliewer et al. 1999; Wang et al. 2008b). The physiological ligands of FXR are BAs (Makishima et al. 1999; Wang et al. 1999), and chenodeoxycholic acid (CDCA) is a typical natural ligand of FXR (Gustafsson 1999). FXR regulates various physiological activities such as cholesterol catabolism (Russell 1999), liver regeneration (Chen et al. 2010; Zhang et al. 2012), inflammation and immunoreaction (Wang et al. 2008c), and glucose metabolism through different pathways (Pathak et al. 2018). These reports indicate that FXR is an essential regulator in vivo.

The earliest evidence of FXR-microbiota crosstalk was discovered in a study involving the treatment of the mice with antioxidant tempol, leading to the decrease of the genus Lactobacillus and bile salt hydrolase (BSH) and eventually the accumulation of intestinal Tauro$\beta$-muricholic acid (T- $\beta$-MCA), an FXR antagonist ( $\mathrm{Li}$ et al. 2013). Another report showed that the gut microbiota regulates bile acid metabolism and inhibits the synthesis of BAs in the liver by regulating the expression of fibroblast growth factor 15 (FGF15) in the ileum and cholesterol $7 \alpha$-hydroxylase (CYP7A1) in the liver. Tauroconjugated beta and alpha-muricholic acids were also identified as the antagonists of FXR (Degirolamo et al. 2014; Gonzalez et al. 2016; Sayin et al. 2013). These discoveries provided the evidence of the potential connection between the microbiota and FXR. 
Table 1 NRs in the crosstalk of gut microbiome-host system

\begin{tabular}{|c|c|c|c|}
\hline NRs & Mechanism & Diseases and phenotype & References \\
\hline \multirow[t]{7}{*}{ FXR } & $\begin{array}{l}\text { Tempol } \rightarrow \text { Lactobacillus } \downarrow \text {, } \\
\mathrm{BSH} \downarrow \rightarrow \text { T- } \beta \text {-MCA } \uparrow \rightarrow \text { inhibition of FXR }\end{array}$ & Obesity & Li et al. (2013) \\
\hline & Gut microbiome $\rightarrow$ FXR $\rightarrow$ FGF15/19 or CYP7A1 & Multi-Metabolic diseases & $\begin{array}{l}\text { Al-Khaifi et al. (2018); Degirolamo et al. (2014); Gonzalez } \\
\text { et al. (2016); Sayin et al. (2013) }\end{array}$ \\
\hline & $\begin{array}{l}\text { Gut microbiome } \rightarrow \text { FXR } \rightarrow \\
\text { Diet-induced obesity }\end{array}$ & Obesity & Parséus et al. (2017) \\
\hline & $\begin{array}{l}\text { FXR } \downarrow \rightarrow \text { ceramide } \downarrow \rightarrow \\
\text { SREBP- } 1 \text { C } \downarrow \rightarrow \\
\text { lipid metabolism } \downarrow \text {, Obesity } \downarrow\end{array}$ & Obesity, NAFLD & Gonzalez et al. (2016); Jiang et al. (2015) \\
\hline & $\begin{array}{l}\mathrm{FEX} \rightarrow \mathrm{FXR} \rightarrow \mathrm{TGR} 5 \rightarrow \mathrm{GLP}-1 \rightarrow \text { improving glucose } \& \\
\text { insulin tolerance }\end{array}$ & $\mathrm{T} 2 \mathrm{D}$ & Albaugh et al. (2019); Pathak et al. (2018) \\
\hline & FXR $\downarrow \rightarrow$ butyrate producers in gut microbiome $\downarrow$ & NAFLD & Sheng et al. (2017) \\
\hline & $\begin{array}{l}\text { Gut microbiome } \rightarrow \text { primary BAs change to secondary } \\
\text { BAs } \rightarrow \text { FXR-FGF pathway }\end{array}$ & IBD, NAFLD & Jiao et al. (2018) \\
\hline \multirow[t]{6}{*}{ PPARs } & $\begin{array}{l}\text { Prevotella and Atopobium } \rightarrow \text { SCFAs } \rightarrow \text { ERK1/2- } \\
\text { PPARY } \rightarrow \text { ANGPTL } 4 \uparrow, \text { ADRP } \uparrow\end{array}$ & Epithelial damage & Nepelska et al. (2017) \\
\hline & Bacteroides $\rightarrow$ insulin sensitive regulation & glucose metabolism & Yang et al. (2017) \\
\hline & PPARa $\rightarrow \| L-22$, Reg $\| \mid \beta$, Reg $\| \gamma$ & Gut mucosal immunity & Manoharan et al. (2016) \\
\hline & $\begin{array}{l}\text { Lactic acid bacteria } \rightarrow \text { ALA } \rightarrow \text { GPCR40 } \rightarrow \text { microphage } \\
\text { M2 differentiation }\end{array}$ & Gut mucosal immunity & Ohue-Kitano et al. (2018) \\
\hline & $\begin{array}{l}\text { Microbiome } \rightarrow \text { lack of butyrate } \rightarrow \text { absence of PPARy } \\
\text { signal } \rightarrow \text { nitrate and lactate accumulate } \rightarrow \text { exogenous } \\
\text { infection }\end{array}$ & IBD, NAFLD & Byndloss et al. (2017); Gillis et al. (2018) \\
\hline & L.casei Zhang $\rightarrow$ TLR-MAPK-PPARY $\rightarrow$ inflammation $\downarrow$ & Liver inflammation & Wang et al. (2016b) \\
\hline \multirow[t]{8}{*}{ AHR } & $\begin{array}{l}\text { Ethanol } \rightarrow \text { IAA-AHR-IL-22-REG3G pathway } \rightarrow \text { gut } \\
\text { bacteria transfer }\end{array}$ & Liver inflammation & Hendrikx et al. (2018) \\
\hline & Trp metabolism $\rightarrow$ CARD9-AHR-IL-22 & $\mathrm{IBD}$ & Lamas et al. (2017) \\
\hline & Gut microbiome $\rightarrow \mathrm{CD}^{+}{ }^{-}$-LAG3 pathway & CNS immunity & Kadowaki et al. (2016) \\
\hline & $\mathrm{AHR} \rightarrow \mathrm{ROR} \gamma+$ group $3 \mathrm{ILC}$ & $\mathrm{IBD}$ & Qiu and Zhou (2013) \\
\hline & $\begin{array}{l}\text { ILC } \rightarrow \text { inhibitor of DNA binding } 2 \text { (ID2)-AHR-IL-22 } \\
\text { pathway or T cell }\end{array}$ & $\mathrm{IBD}$ & Guo et al. (2015); Wagage et al. (2015) \\
\hline & Urolithin A $\rightarrow$ AHR-Nrf2 pathway & Gut barrier integrity & Singh et al. (2019) \\
\hline & $\begin{array}{l}\text { gut microbiome } \rightarrow \text { Trp metabolism } \rightarrow \text { indole deriva- } \\
\text { tives } \rightarrow \text { AHR-IL-22 signal } \rightarrow \text { antifungal resistance and } \\
\text { mucosal protection }\end{array}$ & Gut mucosal reactivity & Zelante et al. (2013) \\
\hline & Purinergic metabolism $\rightarrow$ AHR-CD39 pathway & Immune metabolism & Longhi et al. (2017) \\
\hline \multirow[t]{4}{*}{ VDR } & VD-VDR $\rightarrow$ NF-kB, MAPKs, TLR, EGFR, TJ pathways & IBD, Eystic fibrosis & $\begin{array}{l}\text { Kanhere et al. (2018); Wu et al. (2010); Yoon and Sun } \\
\text { (2011) }\end{array}$ \\
\hline & VDR $\rightarrow$ Th1, Th17 cell & $\begin{array}{l}\text { Mucosa inflammation, } \\
\text { Epithelium cell apoptosis }\end{array}$ & He et al. (2018) \\
\hline & $\begin{array}{l}\text { Lactobacillus casei Zhang and Vitamin } \\
\mathrm{K} 2 \rightarrow \mathrm{VDR} \rightarrow \text { AMPK signaling pathway }\end{array}$ & Colon cancer & Zhang et al. (2017) \\
\hline & VDR $\rightarrow$ ATG16L1 $\rightarrow$ autophagy & IBD, autophagy & Jin et al. (2015) \\
\hline
\end{tabular}

Microbiota-FXR-FGF is a typical pathway of the gut microbiota-FXR-host axis. FXR targets FGF15 in mice and FGF19 in humans, respectively (Al-Khaifi et al. 2018). This pathway is related to obesity. The treatment of obesity includes the use of weight loss pills (Pathak et al. 2018) and Bariatric Surgery (Albaugh et al. 2017; Bozadjieva et al. 2018), etc. As shown in the reports, FXR-microbiota showed obesity promoting activity by increasing fatty acid transportation (Parséus et al.
2017), which was contrary to the previous cognition of FXR (Fang et al. 2015). In the intestine, the gut microbiota modulates the activity of FXR by regulating bile acid metabolism. The level of T- $\beta$-MCA, an antagonist of FXR, is regulated by $\mathrm{BSH}$, an enzyme expressed in Lactobacillus, Bacteroides, Clostridium and Bifidobacterium in the gut microbiome. In some cases, for example, tempol treatment in mice, decreased these bacteria and BSH activity in the intestine and increased 
T- $\beta$-MCA level, and then inhibited FXR activation, resulting in suppressing the synthesis of ceramide to prevent hepatic steatosis (Jiang et al. 2015), glucose intolerance and obesity (Gonzalez et al. 2016; Jiang et al. 2015; Turpin et al. 2014).

Besides, Type 2 Diabetes (T2D) associated with glucose metabolism is related to the microbiota-FXR axis (Pathak et al. 2018). One of the mechanisms by which the gut microbiota-FXR axis regulates glucose metabolism is the FXR-glucagon-like peptide-1 (GLP1) pathway. The activation of intestinal FXR induced lithocholic acid (LCA)-producing bacteria Acetatifactor and Bacteroides, leading to producing LCA to activate Takeda G protein-coupled receptor-5 (TGR5)/GLP-1 signaling. Then the activation of TGR5/GLP-1 signaling regulated glucose metabolism, improved insulin sensitivity and promoted adipose tissue browning (Albaugh et al. 2019).

The FXR-microbiota axis also plays a key role in the immunopathology of the gut-liver axis and IBD (Chiang and Ferrell 2018; Joyce and Gahan 2016). NAFLD is a series of liver diseases involving chronic inflammations of the liver (Chen et al. 2019). SCFAs, butyrate as one of the examples, are the products of the metabolism of the gut microbiota. Down-regulating FXR leads to the downregulation of the butyrate-generating microbes and then the decrease of the levels of butyrate, a regulator of liver inflammation (Sheng et al. 2017). Furthermore, CDCA, a typical agonist of FXR, could be changed into secondary BAs like Deoxycholic acid (DCA) and LCA by the gut microbiota. It then becomes an FXR antagonist and influences NAFLD (Jiao et al. 2018). In IBD, the FXR-FGF axis is also effective through the function of the gut microbiome. The gut microbiome modulates BA pool through the producers such as Firmicutes, Bacteroidetes and Actinobacteria to regulate FXR activation (Baars et al. 2015). Then activation of the FXR-FGF19 axis in a murine model of intestinal inflammation could bona fide provide positive changes in BA metabolism with consequent reduction of intestinal inflammation and modulation of microbiota (Duboc et al. 2013; Gadaleta et al. 2020). These roles form the gut microbiome-FXR-FGF cyclic regulation mechanism in IBD. On the other hand, the excess activation of FXR and type I interferon (IFN)I signal within intestinal epithelial cells after a Western diet consumption can induce Paneth cell defects and destroy intestinal homeostasis, affecting the gut microbiota in the host (Liu et al. 2021). Thus, FXR and the gut microbiome have a relationship of mutual influence and regulation in the intestine. The functions of FXR in the microbiota-host system have been reported more than the other NRs. We have summarized a part of the findings in Fig. 1 as a signaling map.

\section{Gut microbiota and PPARs}

PPARs, including PPAR $\alpha, \beta, \gamma, \delta$, are a series of nuclear receptors sub-family and were first identified and cloned in 1990 (Issemann and Green 1990). Early research found that PPARs could be activated by peroxisome proliferators and fatty acids, and then regulate the metabolism of the fatty acids and carcinogenesis (Auwerx 1992; Green 1992). With the increasing number of reports, PPARs have been known as essential regulators that play key roles in various physiology and pathology processes related to not only lipid and fatty acids metabolism, and tumor generation, but also glucose metabolism, inflammation, and immunology (Mirza et al. 2019).

PPARs, as the typical model NRs, play the important roles in the host-gut microbiome crosstalk, and they have been identified as the enteric epithelial homeostasis mediators (Gao et al. 2018a). Angiopoietin-like 4 (ANGTPL4) and adipose differentiation-related protein (ADRP) are both the target genes of PPAR $\gamma$, which in turn could be up-regulated by SCFAs (Butyrate and propionate) and the products of Prevotella and Atopobium. The mechanism underlying this process is the phosphorylation of PPAR $y$ through extracellular signal-regulated kinase (ERK) signaling pathway (Nepelska et al. 2017). And the PPAR- $\gamma$ signal activated by butyrate can inhibit the expression of nitric oxide synthase 2 , reduce the synthesis of inducible nitric oxide synthase to limit luminal nitrate availability, and then inhibit dysbiotic Enterobacteriaceae expansion (Byndloss et al. 2017).

Similar to the FXR, PPARs are also involved in lipid and glucose metabolism, and thus, associated with obesity and diabetes (Gao et al. 2018b; Mishra et al. 2016). According to a recent report, Bacteroides, a member of the microbiome in the gut, seems to play key roles through the host-microbiome crosstalk in regulating diseases related to glucose and lipid metabolism (Zhang et al. 2016). In this process, PPAR $\gamma$ and PPAR $\alpha$ were found at the abnormal expression levels (Nihei et al. 2018), which increased the sensitivity of insulin and prevented obesity (Yang et al. 2017).

PPARs are also involved in microbiome-related immune metabolism and inflammation of the gut-liver axis, such as IBD, Alcoholic Fatty Liver Diseases (AFLD) and NAFLD (Mirza et al. 2019; Sharma et al. 2015). PPAR $\alpha$ has been confirmed to regulate the expression of Interleukin-22 (IL-22), Regenerating islet-derived III $\beta$ (RegIII $\beta$ ), Regenerating islet-derived III $\gamma$ (RegIII $\gamma$ or REG3G) and calprotectin in the innate immune cells, thus, mediating the gut mucosal immunity (Manoharan et al. 2016). Moreover, PPARs are involved in the process of the differentiation of anti-inflammatory M2 macrophages. The underlying mechanisms include the production of $\alpha$-Linolenic acid (ALA) by gut lactic acid 


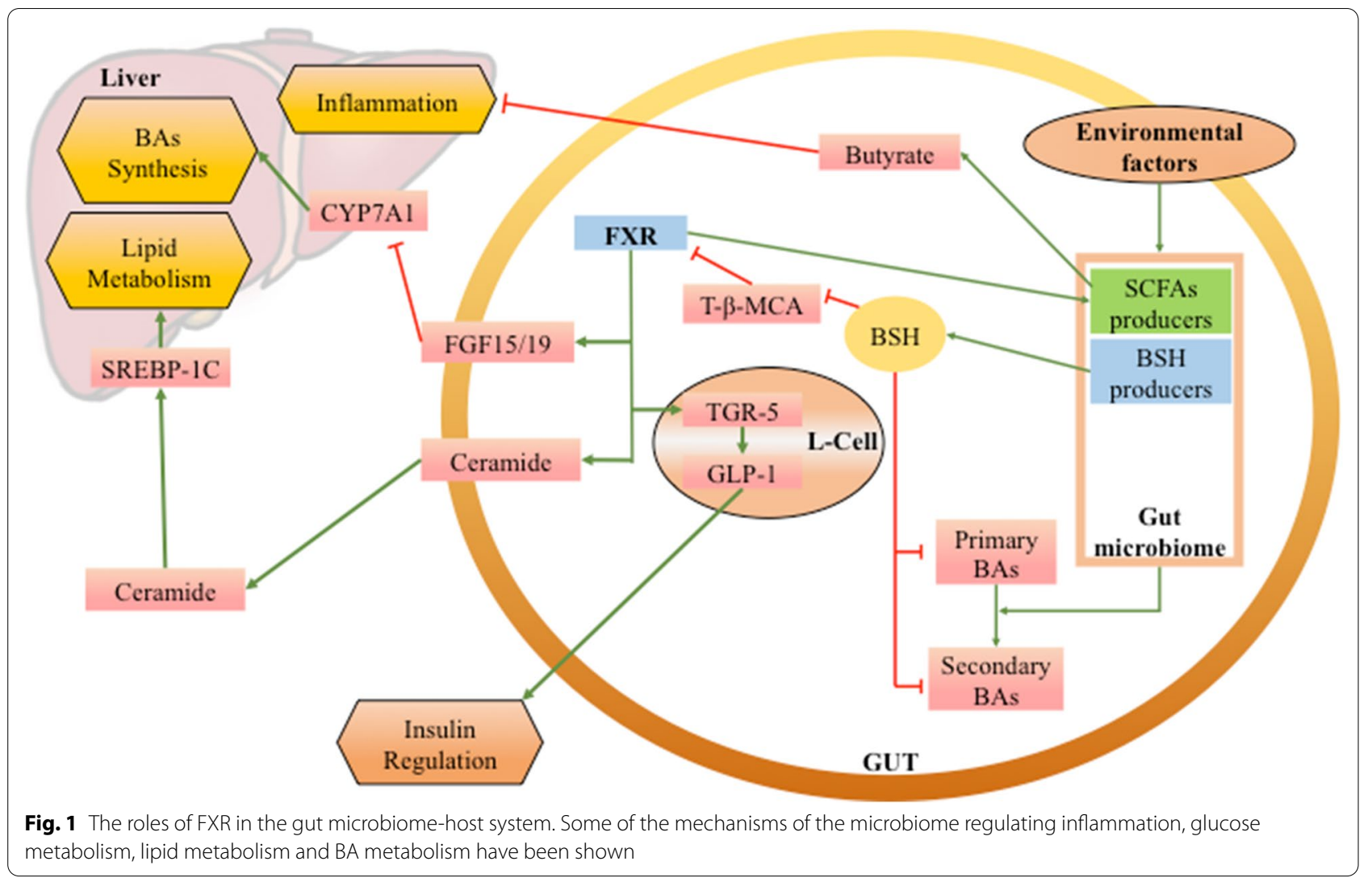

bacteria and subsequent induction of the macrophages through G-protein-coupled receptor 40 (GPCR40) signaling (Ohue-Kitano et al. 2018). PPARs also play key roles in preventing the exogenous infection caused by Escherichia and Salmonella (Byndloss et al. 2017; Gillis et al. 2018). As far as the acute inflammatory response is concerned, some of the probiotics produced by the gut microbiome such as Lactobacillus casei Zhang could reduce the inflammation (Wang et al. 2016b). Moreover, the gut microbiome could mediate PPAR $\gamma$-driven liver circadian clock reprogramming (Murakami et al. 2016). The hepatic physiology follows a daily rhythm and the perturbation of the liver clock results in metabolic disorders such as NAFLD (Crespo et al. 2021) and even liver cancer (Mazzoccoli et al. 2019) through regulating rhythm gene expression and the rhythm-related signaling pathways. Thus, the gut microbiome-PPAR $\gamma$ axis may mediate the circadian clock to affect liver diseases such as NAFLD and cancer.

\section{Gut microbiome and AHR}

AHR was discovered in the 1970s, and identified as a xenobiotic sensor mediating the toxicity of 2,3,7,8-tetrachlorodibenzo-p-dioxin (TCCD) initially (Guenthner and Nebert 1977; Lee et al. 2017). After more than 30 years of research, more and more functions of AHR have been identified, including the detoxing mediator, aromatic molecule (such as tryptophan, purine), metabolic regulator, cancer regulator, immune-regulator, barrier organ or cell regulator, etc. (Esser 2016; Esser and Rannug 2015; Murray et al. 2014). Similar to FXR and PPARs, AHR is associated with the gut microbiome due to the crosstalk of the host and microbiome. The ligands of AHR include SCFAs (especially butyrate) which are known as the products of the gut microbiome (Marinelli et al. 2019). Besides, indole, another typical agonist of AHR, is also a product of the host-microbiome metabolism (Rothhammer et al. 2016).

AHR is a regulator of inflammation and immune metabolism especially in the central nerve system (CNS), intestinal barrier, lymphatic system, and alcoholic hepatitis. Ethanol decomposition leads to the abnormal states of indole-3-acetic acid (IAA)-IL-22-REG3G signaling pathway and results in the transfer of the bacteria to the liver, thus, leading to the inflammation of the liver (Hendrikx et al. 2018). Apart from liver diseases, IBD and CNS immune regulation is also related to AHR (Hendrikx et al. 2018; Lee et al. 2017). The main underlying mechanisms are Caspase recruitment domain-containing protein 9 (CARD9) and IL-22 signal or cluster of differentiation 
4- Lymphocyte-activation gene 3 (CD4 ${ }^{+}$-LAG-3) pathway (Kadowaki et al. 2016; Lamas et al. 2017). Besides, IBD is associated with the lymphatic system, which is mainly related to group-3-innate lymphoid cells (group3-ILC)-induced cellular immunity (Guo et al. 2015; Qiu and Zhou 2013; Wagage et al. 2015).

Tryptophan (Trp) metabolism of the gut microbiome also plays a key role in IBD (Lamas et al. 2016b; Longhi et al. 2017). This is related to the regulation of the gut barrier integrity and the mucosal reactivity by AHR (Singh et al. 2019; Zelante et al. 2013). Trp in the intestine could be changed to AHR ligand (including indole) by the microbiome metabolism and then can regulate multiple pathways, including IL22 signaling, AHR-xenobiotics metabolism, GLP-1 secretions, and gut-brain (CNS) axis (Agus et al. 2018). Besides, purinergic metabolism is another process that is regulated by AHR. This is associated with the immune metabolism of the intestine through targeting Cluster of Differentiation 39 (CD39) in IBD (Longhi et al. 2017).

\section{Gut microbiome and VDR}

VDR was identified as a transcription factor belonging to the nuclear receptor superfamily (Makishima 2017); this was confirmed in diverse sources such as chicken intestine (Wecksler and Norman 1980), mouse kidney (Colston and Feldman 1980), and human breast cancer cell lines (Findlay et al. 1980). Vitamin D (1,25(OH)2D3), the ligand of VDR, a sterol and prohormone, is obtained from inactive vitamin D [25(OH)D3] (Del Pinto et al. 2017). Vitamin D regulates various physiological and pathological processes such as phosphate and calcium cycle, inflammation, immune response, and cancer, etc. (Colotta et al. 2017; Shang and Sun 2017). After activation by vitamin D, VDR could bind with RXR and forms a heterodimer just like FXR (Yoon and Sun 2011). The relationship between VDR and the gut microbiome could be understood by some phenotype research. However, the underlying mechanism is mostly unknown due to the lack of relevant studies. So far, it has been identified that the VDR-Vitamin D axis plays the key roles in IBD (Del Pinto et al. 2017), gut Vitamin D regulation (Barbáchano et al. 2017), microbiome homeostasis, epithelium and mucosal regulation (including immune regulation) (Kanhere et al. 2018), sterol metabolism (Ridlon and Bajaj 2015), and autophagy regulation (Sun 2016).

Cooperating with the gut microbiome, the Vitamin D-VDR axis plays the key roles in intestine inflammation, certainly in IBD, through multiple signaling pathways including NF- $\mathrm{kB}$, Mitogen-activated protein kinase (MAPK), Toll-like receptor (TLR), epidermal growth factor receptor (EGFR), etc. (Wu et al. 2010; Yoon and Sun 2011). And the function of VDR in intestine inflammation regulation is associated with epithelium and mucosa through these mechanisms, which also acts as key roles in cystic fibrosis (Kanhere et al. 2018). In a report of $\mathrm{VDR}^{-1-}$ colon inflammation mouse model, VDR knockout mice showed upregulation of IFN- $\gamma^{+}$and Interleukin $17^{+}\left(\mathrm{IL}_{17}{ }^{+}\right) \mathrm{T}$ cells (Th1 and Th17) that results in the mucosa inflammation and the apoptosis of epithelium cells (He et al. 2018). Besides, Lactobacillus casei Zhang could inhibit colon cancer through multi-signaling (including adenosine monophosphate-activated protein kinase (AMPK) signaling pathway) along with Vitamin K2 (Zhang et al. 2017). At the same time, downregulation of VDR leads to the abnormal autophagic activity and the abnormal states of the gut microbiome by reducing the level of autophagy related 16 like 1 (ATG16L1), which is associated with intestine inflammation (Jin et al. 2015; Sun 2016).

\section{Prospect}

The gut microbiome has been identified as a subsystem that plays the key roles in various complex physiological and pathological processes. NRs have also been confirmed as intermediators in the microbiome-host axis; however, the signal and pathway map is incomplete. As oral medication is one of the most efficient methods in clinical treatment, the gut microbiome could be a medium medicine targeting the NRs. As the roles played by NRs are known to be complex, straightforward targeting of NRs might lead to serious toxic side effects. For example, the previous report has shown that obeticholic acid, a ligand of FXR, leads to an unfavorable serum lipid profile with the increase of total cholesterol and low-density lipoprotein cholesterol and the decrease of high-density lipoprotein cholesterol (Massafra et al. 2018; Mudaliar et al. 2013). Targeting PPAR $\gamma$ can relieve insulin resistance and promote adipogenesis, which makes the role of PPAR $\gamma$ self-contradictory in the treatment of T2D (Lehrke and Lazar 2005). And thiazolidinediones (TZDs, the ligands of PPAR $\gamma$ ) also show a huge risk of clinical application (Ahmadian et al. 2013). However, due to the gut microbiota-NRs-host axis and the regulation of the gut microbiome by diet therapy, indirectly targeting NRs through diet change would be an ideal way to reduce the side effects of NRs caused by the direct ligand application. Hence, the activation of the gut microbiotaNRs-host axis may be used for avoiding some of the risks associated with the toxic effects induced by the NR ligand treatment.

Besides, targeting a single factor seems ineffective in some of the diseases with complex pathological processes. As a complex system, the gut microbiome impacts the host physiology processes through targeting multisignaling pathways and multi-NRs in the due course. 
It implies that many pathological processes are due to a combination of factors rather than a single path. This could be a topic of potential research in the future.

\section{Conclusion}

In summary, NRs are the important mediators between the gut microbiota and the host. The functions of NRs, as the important regulators, in the host can be influenced by the gut microbiome. On the other hand, the condition of the gut microbiome is also affected by NRs, just as FXR has effects on the gut microbiome in IBD (Duboc et al. 2013; Liu et al. 2021). NRs can be identified as a bridge between the gut microbiome and the host.

\begin{abstract}
Abbreviations
ADRP: Adipose differentiation-related protein; AFLD: Alcoholic fatty liver disease; AHR: Aryl hydrocarbon receptor; ALA: a-Linolenic acid; ALD: Alcoholic liver disease; AMPK: Adenosine monophosphate-activated protein kinase; ANGPTL4: Angiopoietin-like 4; ATG16L1: Autophagy related 16 like 1; BAs: Bile acids; BSH: Bile salt hydrolase; CAR: Constitutive androstane receptor; CARD9: Caspase recruitment domain-containing protein 9; CD4: Cluster of differentiation 4; CDCA: Chenodeoxycholic acid; CNS: Central nerve system; CYP7A1: Cholesterol 7a-hydroxylase; DCA: Deoxycholic acid; ERK: Extracellular signalregulated kinase; FGFs: Fibroblast growth factors; FXR: Farnesoid X receptor; GLP-1: Glucagon-like peptide-1; GPCR40: G-protein-coupled receptor 40; IAA: Indole-3-acetic acid; IBD: Inflammatory bowel disease; IFN- $\gamma$ : Interferon gamma; ILC: Innate lymphoid cells; ILs: Interleukins; JNK: C-Jun N-terminal kinases; LAG-3: Lymphocyte-activation gene 3; LCA: Lithocholic acid; LXR: Liver $X$ receptor; MAPK: Mitogen-activated protein kinase; MC-LR: Microcystin-LR; NAFLD: Non-alcoholic fatty liver disease; NALD: Non-alcoholic liver disease; NF-kB: Nuclear factor kappa-light-chain-enhancer of activated B cells; NRs: Nuclear receptors; PPARs: Peroxisome proliferator-activated receptors; PXR: Pregnane and xenobiotic receptor; Reglll: Regenerating islet-derived III; RXR: Retinoid $X$ receptor; SCFAs: Short chain fatty acids; SREBP-1: Sterol regulatory element-binding protein 1;T2D: Type 2 diabetes; TCCD: 2,3,7,8-Tetrachlorodibenzo-p-dioxin; TGR5: Takeda G protein-coupled receptor-5; VD: Vitamin D; VDR: Vitamin D receptor.
\end{abstract}

\section{Acknowledgements}

We apologize to colleagues whose work could not be cited due to space limitations. This work is supported by the National Natural Science Foundation of China (Grant No. 81970551 and No. 81672433), the Fundamental Research Funds for the Central Universities (Grant No. PT2001) to Y.-D.W., the National Natural Science Foundation of China (Grant No. 81970726), Henan Provincial Natural Science Foundation (Grant No.182300410323), Program for Science \& Technology Innovation Talents in Universities of Henan Province (HASTIT, Grant No. 13HASTIT024) and Plan for Scientific Innovation Talent of Henan Province to W.-D.C..

\section{Authors' contributions}

ZW wrote the manuscript, Y-DW and W-DC initiated the ideas for the manuscript, revised the manuscript and received the grant support. All authors read and approved the final manuscript.

\section{Funding}

This work is supported by the National Natural Science Foundation of China (Grant No. 81970551 and No. 81672433), the Fundamental Research Funds for the Central Universities (Grant No. PT2001) to Y.-D.W., the National Natural Science Foundation of China (Grant No. 81970726), Henan Provincial Natural Science Foundation (Grant No.182300410323), Program for Science \& Technology Innovation Talents in Universities of Henan Province (HASTIT, Grant No. 13HASTIT024) and Plan for Scientific Innovation Talent of Henan Province to W.-D.C..
Availability of data and materials

No supporting data.

\section{Declarations}

Ethics Approval and Consent to participate

Confirmed.

\section{Consent for publication \\ Confirmed.}

\section{Competing interests}

The authors have declared that no conflict of interest exists.

\section{Author details}

${ }^{1}$ State Key Laboratory of Chemical Resource Engineering, College of Life Science and Technology, Beijing University of Chemical Technology, Beijing, People's Republic of China. ${ }^{2}$ Key Laboratory of Molecular Pathology, Key Laboratory of Receptors-Mediated Gene Regulation and Drug Discovery, School of Basic Medical Science, Inner Mongolia Medical University, Hohhot, Inner Mongolia, People's Republic of China. ${ }^{3}$ School of Medicine, Key Laboratory of Receptors-Mediated Gene Regulation, The People' Hospital of Hebi, Henan University, Henan, People's Republic of China.

Received: 23 April 2021 Accepted: 26 October 2021

Published online: 05 November 2021

\section{References}

Agus A, Planchais J, Sokol H. Gut microbiota regulation of tryptophan metabolism in health and disease. Cell Host Microbe. 2018;23:716-24.

Ahmadian M, Suh JM, Hah N, Liddle C, Atkins AR, Downes M, Evans RM. PPARy signaling and metabolism: the good, the bad and the future. Nat Med. 2013;19:557-66.

Albaugh VL, Banan B, Ajouz H, Abumrad NN, Flynn CR. Bile acids and bariatric surgery. Mol Aspects Med. 2017;56:75-89.

Albaugh VL, Banan B, Antoun J, Xiong Y, Guo Y, Ping J, Alikhan M, Clements BA, Abumrad NN, Flynn CR. Role of bile acids and GLP-1 in mediating the metabolic improvements of bariatric surgery. Gastroenterology. 2019;156:1041-1051.e1044.

Al-Khaifi A, Rudling M, Angelin B. An FXR agonist reduces bile acid synthesis independently of increases in FGF19 in healthy volunteers. Gastroenterology. 2018;155:1012-6.

Arulampalam V, Greicius G, Pettersson S. The long and winding road to gut homeostasis. Curr Opin Gastroenterol. 2006;22:349-53.

Auwerx J. Regulation of gene expression by fatty acids and fibric acid derivatives: an integrative role for peroxisome proliferator activated receptors. The Belgian Endocrine Society Lecture 1992. Horm Res. 1992;38:269-77.

Baars A, Oosting A, Knol J, Garssen J, van Bergenhenegouwen J. The gut microbiota as a therapeutic target in IBD and metabolic disease: a role for the bile acid receptors FXR and TGR5. Microorganisms. 2015;3:641-66.

Backhed F, Ley RE, Sonnenburg JL, Peterson DA, Gordon Jl. Host-bacterial mutualism in the human intestine. Science (new York, NY). 2005:307:1915-20.

Barbáchano A, Fernández-Barral A, Ferrer-Mayorga G, Costales-Carrera A, Larriba MJ, Muñoz A. The endocrine vitamin D system in the gut. Mol Cell Endocrinol. 2017;453:79-87.

Bozadjieva N, Heppner KM, Seeley RJ. Targeting FXR and FGF19 to treat metabolic diseases-lessons learned from bariatric surgery. Diabetes. 2018:67:1720-8.

Byndloss MX, Olsan EE, Rivera-Chávez F, Tiffany CR, Cevallos SA, Lokken KL, Torres TP, Byndloss AJ, Faber F, Gao Y, Litvak Y, Lopez CA, Xu G, Napoli E, Giulivi C, Tsolis RM, Revzin A, Lebrilla CB, Bäumler AJ. Microbiota-activated PPAR- $\gamma$ signaling inhibits dysbiotic Enterobacteriaceae expansion. Science (new York, NY). 2017;357:570-5.

Cave MC, Clair HB, Hardesty JE, Falkner KC, Feng W, Clark BJ, Sidey J, Shi H, Aqel BA, McClain CJ, Prough RA. Nuclear receptors and nonalcoholic fatty liver disease. Biochim Biophys Acta. 2016;1859:1083-99. 
Chawla A, Repa JJ, Evans RM, Mangelsdorf DJ. Nuclear receptors and lipid physiology: opening the X-files. Science (new York, NY). 2001;294:1866-70.

Chen WD, Wang YD, Zhang L, Shiah S, Wang M, Yang F, Yu D, Forman BM, Huang W. Farnesoid $X$ receptor alleviates age-related proliferation defects in regenerating mouse livers by activating forkhead box $\mathrm{m} 1 \mathrm{~b}$ transcription. Hepatology (baltimore, MD). 2010;51:953-62.

Chen J, Thomsen M, Vitetta L. Interaction of gut microbiota with dysregulation of bile acids in the pathogenesis of nonalcoholic fatty liver disease and potential therapeutic implications of probiotics. J Cell Biochem. 2019;120:2713-20.

Chiang JYL, Ferrell JM. Bile acid metabolism in liver pathobiology. Gene Expr. 2018:18:71-87.

Colotta F, Jansson B, Bonelli F. Modulation of inflammatory and immune responses by vitamin D. J Autoimmun. 2017;85:78-97.

Colston K, Feldman D. Nuclear translocation of the 1,25-dihydroxycholecalciferol receptor in mouse kidney. J Biol Chem. 1980;255:7510-3.

Corrigan ML, Roberts K, Steiger E. Adult short bowel syndrome: nutritional, medical, and surgical management. Amsterdam: Elsevier Science; 2018.

Crespo M, Leiva M, Sabio G. Circadian clock and liver cancer. Cancers (basel). 2021;13(14):3631. https://doi.org/10.3390/cancers13143631.

Degirolamo C, Rainaldi S, Bovenga F, Murzilli S, Moschetta A. Microbiota modification with probiotics induces hepatic bile acid synthesis via downregulation of the Fxr-Fgf15 axis in mice. Cell Rep. 2014;7:12-8.

Del Pinto R, Ferri C, Cominelli F. Vitamin D axis in inflammatory bowel diseases: role, current uses and future perspectives. Int J Mol Sci. 2017;18(11):2360. https://doi.org/10.3390/ijms18112360.

du Teil EM, Gabarrini G, Harmsen HJM, Westra J, van Winkelhoff AJ, van Dijl JM. Talk to your gut: the oral-gut microbiome axis and its immunomodulatory role in the etiology of rheumatoid arthritis. FEMS Microbiol Rev. 2019:43:1-18

Duboc H, Rajca S, Rainteau D, Benarous D, Maubert MA, Quervain E, Thomas G, Barbu V, Humbert L, Despras G, Bridonneau C, Dumetz F, Grill JP, Masliah J, Beaugerie L, Cosnes J, Chazouillères O, Poupon R, Wolf C, Mallet JM, Langella P, Trugnan G, Sokol H, Seksik P. Connecting dysbiosis, bile-acid dysmetabolism and gut inflammation in inflammatory bowel diseases. Gut. 2013;62:531-9.

Esser C. The aryl hydrocarbon receptor in immunity: tools and potential. Methods Mol Biol (clifton, NJ). 2016;1371:239-57.

Esser C, Rannug A. The aryl hydrocarbon receptor in barrier organ physiology, immunology, and toxicology. Pharmacol Rev. 2015;67:259-79.

Fang S, Suh JM, Reilly SM, Yu E, Osborn O, Lackey D, Yoshihara E, Perino A, Jacinto S, Lukasheva Y, Atkins AR, Khvat A, Schnabl B, Yu RT, Brenner DA, Coulter S, Liddle C, Schoonjans K, Olefsky JM, Saltiel AR, Downes M, Evans RM. Intestinal FXR agonism promotes adipose tissue browning and reduces obesity and insulin resistance. Nat Med. 2015:21:159-65.

Federici M. Gut microbiome and microbial metabolites: a new system affecting metabolic disorders. J Endocrinol Invest. 2019;42(9):1011-8.

Feng Q, Chen WD, Wang YD. Gut microbiota: an integral moderator in health and disease. Front Microbiol. 2018;9:151.

Findlay DM, Michelangeli VP, Eisman JA, Frampton RJ, Moseley JM, Maclntyre I, Whitehead R, Martin TJ. Calcitonin and 1,25-dihydroxyvitamin D3 receptors in human breast cancer cell lines. Cancer Res. 1980:40:4764-7.

Forman BM, Goode E, Chen J, Oro AE, Bradley DJ, Perlmann T, Noonan DJ, Burka LT, McMorris T, Lamph WW, Evans RM, Weinberger C. Identification of a nuclear receptor that is activated by farnesol metabolites. Cell. 1995:81:687-93.

Gadaleta RM, Garcia-Irigoyen O, Cariello M, Scialpi N, Peres C, Vetrano S, Fiorino G, Danese S, Ko B, Luo J, Porru E, Roda A, Sabbà C, Moschetta A. Fibroblast growth factor 19 modulates intestinal microbiota and inflammation in presence of Farnesoid X receptor. EBioMedicine. 2020;54: 102719.

Gao XJ, Li T, Wei B, Yan ZX, Hu N, Huang YJ, Han BL, Wai TS, Yang W, Yan R. Bacterial outer membrane vesicles from dextran sulfate sodium-induced colitis differentially regulate intestinal UDP-glucuronosyltransferase 1A1 partially through toll-like receptor 4/mitogen-activated protein kinase/ phosphatidylinositol 3-kinase pathway. Drug Metab Disposit Biol Fate Chem. 2018a;46:292-302.

Gao K, Yang R, Zhang J, Wang Z, Jia C, Zhang F, Li S, Wang J, Murtaza G, Xie H, Zhao H, Wang W, Chen J. Effects of Qijian mixture on type 2 diabetes assessed by metabonomics, gut microbiota and network pharmacology. Pharmacol Res. 2018b;130:93-109.

Gillis CC, Hughes ER, Spiga L, Winter MG, Zhu W, Furtado de Carvalho T, Chanin RB, Behrendt CL, Hooper LV, Santos RL, Winter SE. Dysbiosis-associated change in host metabolism generates lactate to support salmonella growth. Cell Host Microbe. 2018;23:54-64e56.

Gonzalez FJ, Jiang C, Patterson AD. An intestinal microbiota-farnesoid $\mathrm{X}$ receptor axis modulates metabolic disease. Gastroenterology. 2016;151:845-59.

Green S. Peroxisome proliferators: a model for receptor mediated carcinogenesis. Cancer Surv. 1992;14:221-32.

Guenthner TM, Nebert DW. Cytosolic receptor for aryl hydrocarbon hydroxylase induction by polycyclic aromatic compounds. Evidence for structural and regulatory variants among established cell cultured lines. J Biol Chem. 1977;252:8981-9.

Guo X, Liang Y, Zhang Y, Lasorella A, Kee BL, Fu YX. Innate lymphoid cells control early colonization resistance against intestinal pathogens through ID2-dependent regulation of the microbiota. Immunity. 2015:42:731-43.

Gustafsson JA. Seeking ligands for lonely orphan receptors. Science (new York, NY). 1999;284:1285-6.

He L, Liu T, Shi Y, Tian F, Hu H, Deb DK, Chen Y, Bissonnette M, Li YC. Gut epithelial vitamin D receptor regulates microbiota-dependent mucosal inflammation by suppressing intestinal epithelial cell apoptosis. Endocrinology. 2018;159:967-79.

Hendrikx T, Duan Y, Wang Y, Oh JH, Alexander LM, Huang W, Starkel P, Ho SB, Gao B, Fiehn O, Emond P, Sokol H, van Pijkeren JP, Schnabl B. Bacteria engineered to produce IL-22 in intestine induce expression of REG3G to reduce ethanol-induced liver disease in mice. Gut. 2018;68(8):1504-15. https://doi.org/10.1136/gutjnl-2018-317232.

Hubbard TD, Murray IA, Bisson WH, Lahoti TS, Gowda K, Amin SG, Patterson $A D$, Perdew GH. Adaptation of the human aryl hydrocarbon receptor to sense microbiota-derived indoles. Sci Rep. 2015;5:12689.

Issemann I, Green S. Activation of a member of the steroid hormone receptor superfamily by peroxisome proliferators. Nature. 1990;347:645-50.

Jiang C, Xie C, Li F, Zhang L, Nichols RG, Krausz KW, Cai J, Qi Y, Fang ZZ, Takahashi S, Tanaka N, Desai D, Amin SG, Albert I, Patterson AD, Gonzalez FJ. Intestinal farnesoid $\mathrm{X}$ receptor signaling promotes nonalcoholic fatty liver disease. J Clin Invest. 2015;125:386-402.

Jiao N, Baker SS, Chapa-Rodriguez A, Liu W, Nugent CA, Tsompana M, Mastrandrea L, Buck MJ, Baker RD, Genco RJ, Zhu R, Zhu L. Suppressed hepatic bile acid signalling despite elevated production of primary and secondary bile acids in NAFLD. Gut. 2018;67:1881-91.

Jin D, Wu S, Zhang YG, Lu R, Xia Y, Dong H, Sun J. Lack of vitamin D receptor causes dysbiosis and changes the functions of the murine intestinal microbiome. Clin Ther. 2015:37:996-1009.e1007.

Joyce SA, Gahan CG. Bile acid modifications at the microbe-host interface: potential for nutraceutical and pharmaceutical interventions in host health. Annu Rev Food Sci Technol. 2016;7:313-33.

Kadowaki A, Miyake S, Saga R, Chiba A, Mochizuki H, Yamamura T. Gut environment-induced intraepithelial autoreactive CD4(+) T cells suppress central nervous system autoimmunity via LAG-3. Nat Commun. 2016:7:11639

Kanhere M, Chassaing B, Gewirtz AT, Tangpricha V. Role of vitamin D on gut microbiota in cystic fibrosis. J Steroid Biochem Mol Biol. 2018;175:82-7.

Kliewer SA, Lehmann JM, Willson TM. Orphan nuclear receptors: shifting endocrinology into reverse. Science (new York, NY). 1999;284:757-60.

Kurilshikov A, Wijmenga C, Fu J, Zhernakova A. Host genetics and gut microbiome: challenges and perspectives. Trends Immunol. 2017;38:633-47.

Lamas B, Richard ML, Sokol H. CARD9 is involved in the recovery of colitis by promoting the production of AhR ligands by the intestinal microbiota. Med Sci: M/s. 2016a;32:933-6.

Lamas B, Richard ML, Leducq V, Pham HP, Michel ML, Da Costa G, Bridonneau C, Jegou S, Hoffmann TW, Natividad JM, Brot L, Taleb S, CouturierMaillard A, Nion-Larmurier I, Merabtene F, Seksik P, Bourrier A, Cosnes J, Ryffel B, Beaugerie L, Launay JM, Langella P, Xavier RJ, Sokol H. CARD9 impacts colitis by altering gut microbiota metabolism of tryptophan into aryl hydrocarbon receptor ligands. Nat Med. 2016b;22:598-605.

Lamas B, Richard ML, Sokol H. Caspase recruitment domain 9, microbiota, and tryptophan metabolism: dangerous liaisons in inflammatory bowel diseases. Curr Opin Clin Nutr Metab Care. 2017;20:243-7. 
Lazar MA. Maturing of the nuclear receptor family. J Clin Investig. 2017;127:1123-5.

Lee HU, McPherson ZE, Tan B, Korecka A, Pettersson S. Host-microbiome interactions: the aryl hydrocarbon receptor and the central nervous system. J Mol Med (berl). 2017;95:29-39.

Lehrke M, Lazar MA. The many faces of PPARgamma. Cell. 2005;123:993-9.

Li F, Jiang C, Krausz KW, Li Y, Albert I, Hao H, Fabre KM, Mitchell JB, Patterson AD, Gonzalez FJ. Microbiome remodelling leads to inhibition of intestinal farnesoid $\mathrm{X}$ receptor signalling and decreased obesity. Nat Commun. 2013:4:2384.

Liu TC, Kern JT, Jain U, Sonnek NM, Xiong S, Simpson KF, VanDussen KL, Winkler ES, Haritunians T, Malique A, Lu Q, Sasaki Y, Storer C, Diamond MS, Head RD, McGovern DPB, Stappenbeck TS. Western diet induces Paneth cell defects through microbiome alterations and farnesoid $X$ receptor and type I interferon activation. Cell Host Microbe. 2021;29:988-1001.e1006.

Longhi MS, Moss A, Jiang ZG, Robson SC. Purinergic signaling during intestinal inflammation. J Mol Med (berl). 2017;95:915-25.

Makishima M. Update on recent progress in vitamin D research. Vitamin D receptor and the nuclear receptor superfamily. Clin Calcium. 2017:27:1533-41.

Makishima M, Okamoto AY, Repa JJ, Tu H, Learned RM, Luk A, Hull MV, Lustig KD, Mangelsdorf DJ, Shan B. Identification of a nuclear receptor for bile acids. Science (new York, NY). 1999;284:1362-5.

Manoharan I, Suryawanshi A, Hong Y, Ranganathan P, Shanmugam A, Ahmad S, Swafford D, Manicassamy B, Ramesh G, Koni PA, Thangaraju M, Manicassamy $\mathrm{S}$. Homeostatic PPARa signaling limits inflammatory responses to commensal microbiota in the intestine. J Immunol (baltimore, Md: 1950). 2016;196:4739-49.

Marinelli L, Martin-Gallausiaux C, Bourhis JM, Beguet-Crespel F, Blottiere HM, Lapaque N. Identification of the novel role of butyrate as AhR ligand in human intestinal epithelial cells. Sci Rep. 2019;9:643.

Massafra V, Pellicciari R, Gioiello A, van Mil SWC. Progress and challenges of selective Farnesoid X Receptor modulation. Pharmacol Ther. 2018;191:162-77.

Mazzoccoli G, Miele L, Marrone G, Mazza T, Vinciguerra M, Grieco A. A role for the biological clock in liver cancer. Cancers (Basel). 2019;11(11):1778.

Mir SA, Nagy-Szakal D, Dowd SE, Szigeti RG, Smith CW, Kellermayer R. Prenatal methyl-donor supplementation augments colitis in young adult mice. PLOS ONE. 2013;8: e73162.

Mirza AZ, Althagafi II, Shamshad H. Role of PPAR receptor in different diseases and their ligands: physiological importance and clinical implications. Eur J Med Chem. 2019;166:502-13.

Mishra AK, Dubey V, Ghosh AR. Obesity: an overview of possible role(s) of gut hormones, lipid sensing and gut microbiota. Metab Clin Exp. 2016;65:48-65.

Mudaliar S, Henry RR, Sanyal AJ, Morrow L, Marschall HU, Kipnes M, Adorini L, Sciacca Cl, Clopton P, Castelloe E, Dillon P, Pruzanski M, Shapiro D. Efficacy and safety of the farnesoid $X$ receptor agonist obeticholic acid in patients with type 2 diabetes and nonalcoholic fatty liver disease. Gastroenterology. 2013;145:574-582.e571.

Murakami M, Tognini P, Liu Y, Eckel-Mahan KL, Baldi P, Sassone-Corsi P. Gut microbiota directs PPARY-driven reprogramming of the liver circadian clock by nutritional challenge. EMBO Rep. 2016;17:1292-303.

Murray IA, Patterson AD, Perdew GH. Aryl hydrocarbon receptor ligands in cancer: friend and foe. Nat Rev Cancer. 2014;14:801-14.

Nepelska M, de Wouters T, Jacouton E, Béguet-Crespel F, Lapaque N, Doré J, Arulampalam V, Blottière HM. Commensal gut bacteria modulate phosphorylation-dependent PPARY transcriptional activity in human intestinal epithelial cells. Sci Rep. 2017;7:43199.

Nihei N, Okamoto H, Furune T, Ikuta N, Sasaki K, Rimbach G, Yoshikawa Y, Terao K. Dietary a-cyclodextrin modifies gut microbiota and reduces fat accumulation in high-fat-diet-fed obese mice. BioFactors (oxford England). 2018. https://doi.org/10.1002/biof.1429.

Ohue-Kitano R, Yasuoka Y, Goto T, Kitamura N, Park SB, Kishino S, Kimura I, Kasubuchi M, Takahashi H, Li Y, Yeh YS, Jheng HF, Iwase M, Tanaka M, Masuda S, Inoue T, Yamakage H, Kusakabe T, Tani F, Shimatsu A, Takahashi N, Ogawa J, Satoh-Asahara N, Kawada T. a-Linolenic acid-derived metabolites from gut lactic acid bacteria induce differentiation of antiinflammatory M2 macrophages through G protein-coupled receptor 40. FASEB J. 2018;32:304-18.
Parséus A, Sommer N, Sommer F, Caesar R, Molinaro A, Ståhlman M, Greiner TU, Perkins R, Bäckhed F. Microbiota-induced obesity requires farnesoid $X$ receptor. Gut. 2017:66:429-37.

Pathak P, Xie C, Nichols RG, Ferrell JM, Boehme S, Krausz KW, Patterson AD, Gonzalez FJ, Chiang JYL. Intestine farnesoid X receptor agonist and the gut microbiota activate G-protein bile acid receptor-1 signaling to improve metabolism. Hepatology (baltimore, MD). 2018;68:1574-88.

Qiu J, Zhou L. Aryl hydrocarbon receptor promotes RORyt ${ }^{+}$group 3 ILCs and controls intestinal immunity and inflammation. Semin Immunopathol. 2013;35:657-70.

Ridlon JM, Bajaj JS. The human gut sterolbiome: bile acid-microbiome endocrine aspects and therapeutics. Acta Pharm Sinica B. 2015;5:99-105.

Rothhammer V, Mascanfroni ID, Bunse L, Takenaka MC, Kenison JE, Mayo L, Chao CC, Patel B, Yan R, Blain M, Alvarez Jl, Kébir H, Anandasabapathy N, Izquierdo G, Jung S, Obholzer N, Pochet N, Clish CB, Prinz M, Prat A, Antel J, Quintana FJ. Type I interferons and microbial metabolites of tryptophan modulate astrocyte activity and central nervous system inflammation via the aryl hydrocarbon receptor. Nat Med. 2016;22:586-97.

Roy A, Kundu M, Jana M, Mishra RK, Yung Y, Luan CH, Gonzalez FJ, Pahan K. Identification and characterization of PPARalpha ligands in the hippocampus. Nat Chem Biol. 2016;12:1075-83.

Russell DW. Nuclear orphan receptors control cholesterol catabolism. Cell. 1999;97:539-42.

Sayin SI, Wahlström A, Felin J, Jäntti S, Marschall HU, Bamberg K, Angelin B, Hyötyläinen T, Orešič M, Bäckhed F. Gut microbiota regulates bile acid metabolism by reducing the levels of tauro-beta-muricholic acid, a naturally occurring FXR antagonist. Cell Metab. 2013;17:225-35.

Shang M, Sun J. Vitamin D/NDR, probiotics, and gastrointestinal diseases. Curr Med Chem. 2017;24:876-87.

Shapiro H, Kolodziejczyk AA, Halstuch D, Elinav E. Bile acids in glucose metabolism in health and disease. J Exp Med. 2018;215:383-96.

Sharma M, Mitnala S, Vishnubhotla RK, Mukherjee R, Reddy DN, Rao PN. The riddle of nonalcoholic fatty liver disease: progression from nonalcoholic fatty liver to nonalcoholic steatohepatitis. J Clin Exp Hepatol. 2015:5:147-58.

Sheng L, Jena PK, Hu Y, Liu HX, Nagar N, Kalanetra KM, French SW, French SW, Mills DA, Wan YY. Hepatic inflammation caused by dysregulated bile acid synthesis is reversible by butyrate supplementation. J Pathol. 2017:243:431-41.

Singh R, Chandrashekharappa S, Bodduluri SR, Baby BV, Hegde B, Kotla NG, Hiwale AA, Saiyed T, Patel P, Vijay-Kumar M, Langille MGI, Douglas GM, Cheng X, Rouchka EC, Waigel SJ, Dryden GW, Alatassi H, Zhang HG, Haribabu B, Vemula PK, Jala VR. Enhancement of the gut barrier integrity by a microbial metabolite through the Nrf2 pathway. Nat Commun. 2019;10:89.

Sun J.VDR/vitamin D receptor regulates autophagic activity through ATG16L1. Autophagy. 2016;12:1057-8.

Tremaroli V, Backhed F. Functional interactions between the gut microbiota and host metabolism. Nature. 2012;489:242-9.

Turpin SM, Nicholls HT, Willmes DM, Mourier A, Brodesser S, Wunderlich CM, Mauer J, Xu E, Hammerschmidt P, Brönneke HS, Trifunovic A, LoSasso G, Wunderlich FT, Kornfeld JW, Blüher M, Krönke M, Brüning JC. Obesityinduced CerS6-dependent C16:0 ceramide production promotes weight gain and glucose intolerance. Cell Metab. 2014;20:678-86.

Viladomiu M, Hontecillas R, Yuan L, Lu P, Bassaganya-Riera J. Nutritional protective mechanisms against gut inflammation. J Nutr Biochem. 2013;24:929-39.

Wagage S, Harms Pritchard G, Dawson L, Buza EL, Sonnenberg GF, Hunter CA. The group 3 innate lymphoid cell defect in aryl hydrocarbon receptor deficient mice is associated with T cell hyperactivation during intestinal infection. PLoS ONE. 2015;10: e0128335.

Wahlstrom A, Sayin SI, Marschall HU, Backhed F. Intestinal crosstalk between bile acids and microbiota and its impact on host metabolism. Cell Metab. 2016;24:41-50.

Wang H, Chen J, Hollister K, Sowers LC, Forman BM. Endogenous bile acids are ligands for the nuclear receptor FXR/BAR. Mol Cell. 1999;3:543-53.

Wang YD, Chen WD, Moore DD, Huang W. FXR: a metabolic regulator and cell protector. Cell Res. 2008a;18:1087-95.

Wang YD, Chen WD, Huang W. FXR, a target for different diseases. Histol Histopathol. 2008b;23:621-7. 
Wang YD, Chen WD, Wang M, Yu D, Forman BM, Huang W. Farnesoid X receptor antagonizes nuclear factor kappaB in hepatic inflammatory response. Hepatology (baltimore, MD). 2008c;48:1632-43.

Wang J, Thingholm LB, Skieceviciene J, Rausch P, Kummen M, Hov JR, Degenhardt F, Heinsen FA, Ruhlemann MC, Szymczak S, Holm K, Esko T, Sun J, Pricop-Jeckstadt M, Al-Dury S, Bohov P, Bethune J, Sommer F, Ellinghaus D, Berge RK, Hubenthal M, Koch M, Schwarz K, Rimbach G, Hubbe P, Pan WH, Sheibani-Tezerji R, Hasler R, Rosenstiel P, D'Amato M, Cloppenborg-Schmidt K, Kunzel S, Laudes M, Marschall HU, Lieb W, Nothlings U, Karlsen TH, Baines JF, Franke A. Genome-wide association analysis identifies variation in vitamin D receptor and other host factors influencing the gut microbiota. Nat Genet. 2016a;48:1396-406.

Wang Y, Xie J, Li Y, Dong S, Liu H, Chen J, Wang Y, Zhao S, Zhang Y, Zhang H. Probiotic Lactobacillus casei Zhang reduces pro-inflammatory cytokine production and hepatic inflammation in a rat model of acute liver failure. Eur J Nutr. 2016b;55:821-31.

Wecksler WR, Norman AW. Measurement of kinetic rate constants for the binding of 1 alpha, 25-dihydroxyvitamin D3 to its chick intestinal mucosa receptor using a hydroxyapatite batch assay. Methods Enzymol. 1980;67:488-94

Wu S, Liao AP, Xia Y, Li YC, Li JD, Sartor RB, Sun J. Vitamin D receptor negatively regulates bacterial-stimulated NF-kappaB activity in intestine. Am J Pathol. 2010;177:686-97.

Wu S, Zhang YG, Lu R, Xia Y, Zhou D, Petrof EO, Claud EC, Chen D, Chang EB, Carmeliet $\mathrm{G}$, Sun J. Intestinal epithelial vitamin D receptor deletion leads to defective autophagy in colitis. Gut. 2015;64:1082-94.

Yang JY, Lee YS, Kim Y, Lee SH, Ryu S, Fukuda S, Hase K, Yang CS, Lim HS, Kim MS, Kim HM, Ahn SH, Kwon BE, Ko HJ, Kweon MN. Gut commensal Bacteroides acidifaciens prevents obesity and improves insulin sensitivity in mice. Mucosal Immunol. 2017;10:104-16.

Yoon SS, Sun J. Probiotics, nuclear receptor signaling, and anti-inflammatory pathways. Gastroenterol Res Pract. 2011;2011: 971938.
Zelante T, lannitti RG, Cunha C, De Luca A, Giovannini G, Pieraccini G, Zecchi R, D'Angelo C, Massi-Benedetti C, Fallarino F, Carvalho A, Puccetti P, Romani L. Tryptophan catabolites from microbiota engage aryl hydrocarbon receptor and balance mucosal reactivity via interleukin-22. Immunity. 2013;39:372-85.

Zenata O, Vrzal R. Fine tuning of vitamin D receptor (VDR) activity by posttranscriptional and post-translational modifications. Oncotarget. 2017:8:35390-402.

Zhang L, Wang YD, Chen WD, Wang X, Lou G, Liu N, Lin M, Forman BM, Huang W. Promotion of liver regeneration/repair by farnesoid $X$ receptor in both liver and intestine in mice. Hepatology (baltimore, MD). 2012;56:2336-43.

Zhang Z, Zhang XX, Wu B, Yin J, Yu Y, Yang L. Comprehensive insights into microcystin-Ir effects on hepatic lipid metabolism using cross-omics technologies. J Hazard Mater. 2016;315:126-134.

Zhang Y, Ma C, Zhao J, Xu H, Hou Q, Zhang H. Lactobacillus casei Zhang and vitamin K2 prevent intestinal tumorigenesis in mice via adiponectinelevated different signaling pathways. Oncotarget. 2017;8:24719-27.

Zhao L, Zhang F, Ding X, Wu G, Lam YY, Wang X, Fu H, Xue X, Lu C, Ma J, Yu L, Xu C, Ren Z, Xu Y, Xu S, Shen H, Zhu X, Shi Y, Shen Q, Dong W, Liu R, Ling Y, Zeng Y, Wang X, Zhang Q, Wang J, Wang L, Wu Y, Zeng B, Wei $H$, Zhang M, Peng Y, Zhang C. Gut bacteria selectively promoted by dietary fibers alleviate type 2 diabetes. Science. 2018;359:1151-6.

Zheng X, Huang F, Zhao A, Lei S, Zhang Y, Xie G, Chen T, Qu C, Rajani C, Dong $B$, Li D, Jia W. Bile acid is a significant host factor shaping the gut microbiome of diet-induced obese mice. BMC Biol. 2017;15:120.

\section{Publisher's Note}

Springer Nature remains neutral with regard to jurisdictional claims in published maps and institutional affiliations.
Ready to submit your research? Choose BMC and benefit from:

- fast, convenient online submission

- thorough peer review by experienced researchers in your field

- rapid publication on acceptance

- support for research data, including large and complex data types

- gold Open Access which fosters wider collaboration and increased citations

- maximum visibility for your research: over 100M website views per year

At BMC, research is always in progress.

Learn more biomedcentral.com/submissions 